\title{
The Ecological Theology of the Indonesian Gayo Tribe: The Integration of Tawhīd Values into Their Trade Tradition
}

\author{
DOl 10.18196/afkaruna.v17i2.11520
}

\section{SUKIMAN}

Ushuluddin Faculty, State Islamic University of North Sumatera (UINSU), Medan, Indonesia mrsukiman133@gmail.com

\begin{abstract}
This study analyzes the process of integration of tawhid (believing in one God) values with trade tradition among the Gayo tribe, which helped to improve their economy and create a more prosperous way of life. This tribe is domiciled in the central region of Aceh, whose origins are Old Malays, and they have lived for a long time in the highlands of Gayo.Thus, they were involved in typical economic activities such as farming, gardening, fishing, rearing of livestock, as well as household businesses and tourism, which were carried out systemically and periodically by the government and jointly supervised by agricultural experts. However, every work carried out had monotheism values with an emphasis on faith and worship because all natural resources were believed to be owned by Allah SWT. This study uses a qualitative approach in which the data collected were in the form of words, images, and not numbers. Results revealed that by capitalizing on faith and piety, the Gayo tribe believes that they can achieve happiness and blessings like the people of Gayo Land who strictly practice Islam in their daily lives and have a blessed, prosperous and dignified life from God.
\end{abstract}

Keywords: Theology, Economy, Gayo Tribe, Sadaqah

\footnotetext{
ABSTRAK

Penelitian ini menganalisis proses integrasi nilai tauhid (ketuhanan) dengan tradisi perdagangan di kalangan suku Gayo yang membantu meningkatkan perekonomian mereka dan menciptakan kehidupan yang lebih sejahtera. Suku ini berdomisili di wilayah tengah Aceh yang berasal dari Melayu Kuno, dan mereka sudah lama tinggal di dataran tinggi Gayo. Mereka melakukan berbagai kegiatan ekonomi seperti bertani, berkebun, memancing, memelihara ternak, serta usaha rumah tangga dan pariwisata, yang dilakukan secara sistemik dan berkala oleh pemeritah dan diawasi bersama oleh para ahli pertanian. Namun, setiap pekerjaan yang dilakukan
} 
memiliki nilai tauhid dengan penekanan pada iman dan ibadah karena semua sumber daya alam diyakini milik Allah SWT. Penelitian ini menggunakan pendekatan kualitatif di mana data yang dikumpulkan berupa kata-kata dan gambar, bukan angka. Hasil penelitian mengungkapkan bahwa dengan bermodalkan keimanan dan ketakwaan, suku Gayo meyakini bahwa mereka dapat meraih kebahagiaan dan berkah seperti masyarakat Tanah Gayo yang secara tegas mengamalkan agama Islam dalam kehidupan seharihari dan memperoleh kehidupan yang barokah, sejahtera dan bermartabat dari Tuhan. Kata kunci: Teologi, Ekonomi, Suku Gayo, Sedekah

\section{INTRODUCTION}

The Gayo tribe is one of the sub-ethnic groups in Aceh, Indonesia. It is domiciled in several districts, including the Central Aceh Regency', Bener Meriah called Gayo Laut, Gayo in Gayo Lues (Belengkejeren) and Southeast Aceh Districts in Cane City as Gayo Deret, as well as Gayo Lukup Serbe in East Aceh Regency.

Islam has been the religion adopted by all Gayo ethnic. They even use Islam in their tribal life system as a guideline for their day-to-day living. The Gayo Highlands region is very beautiful and has the potential for very fertile and abundant natural resources. This area is like a piece of Heaven's land that is placed in the Gayo Mountains so that this nature's gift became a blessing suitable for agronomic purposes for the production of fruits, vegetables and coffee, and also for the purpose of tourism. Thus, the Gayo community carried out their economic activities based on the values of rabbany, which was previously elaborated with the traditions of the ancestors and supported by the environmental influences that existed in Gayo. Meanwhile, they enriched their respective practices with the knowledge that they obtained from formal education. In fact, the Gayo people were involved in various economic activities such as the farming of rice fields (berume), gardening (boiling), rearing livestock (berkude, beritik, bekurik, berkoro), fishing (bergule), trading (mujuel), and entrepreneur businesses. As a matter of fact, most of the Gayo people had diverse economic ventures, and thus, their economy prospered immensely.

Consequently, research on the integrity of the tawhid value in the Gayo community is necessary considering the fact that the Gayo tribe is a community that adheres to a kaffah Islamic religion. This can be seen from from their day-to-day lifestyle as all the rules applied in society are 
based on the teachings of Islam. Therefore, this study analyzed how the tawhïd value of the Gayocommunity tradition is integrated into the livelihoods of the surrounding community to improve their economy and create a more prosperous way of life.

\section{REVIEW OF LITERATURE}

\section{History and Existence of Gayo Tribe}

According to M. J. Melalatoa as the Gayo expert, the history of the Gayo community is still yet to be clearly revealed because historical materials that have been written, besides being very limited, still seem confusing. He stated that no historian had had the opportunity to open the dark veil of the Gayo's history since there is no visible historical evidence that is considered as prominent, plus the fact that the members of the Gayo community themselves are relatively small and remote in the interior of Gayo Region². According to available information, the Gayo tribe came from Old Malay descendants from Thailand and lived in Aceh ${ }^{3}$. Then they finally moved to the interior of Central Aceh, which was also named Gayo Highlands, or "Gayo Land." The Gayo Tribe is synonymous with Islam as well as the Malay tribe ${ }^{4}$, so Islam is a religion adopted by all Gayo ethnic groups wherever they are. Therefore, even their tribal life system uses Islam as its guideline. The Gayo tribe is very careful with Islam so that customs are used as a means for Islamic teachings, which in the term of Gayoedet is the pegerni Agama. Consequently, a number of customs were born which were based on Syarak ${ }^{5}$.

Although the history of the Gayo tribe is still shrouded in darkness, historians say that the first wave of the Gayo tribe came from Old Malaysia who came to Sumatra and settled on the East Coast of Aceh centered in the areas between the Jambu Ayeriver, Perlak River and Temiang River. Then the rivers flowed to Serbejadi, Lingga and Gayo Lues $^{6}$. Also, in the theory of cultural anthropology, the initial domicile of the population was on the seafront before they spread to find a new way of life and atmosphere in the interiors through the rivers. That was how the Old Malay Gayo tribe sought a new life by migrating through the rivers above. Mahmud Ibrahim observed that Perlak residents were the 
oldest of Old Malay tribe who moved to Sumamah, then to Serbajadi, Lingga, Nosar and Isaq via the Penarun river ${ }^{7}$. Even though the Old Malay population migrated to the mountains to seek a new life, they had to move due to the arrival of immigrants from outside Aceh from Gujarat, India, with new patterns and cultural differences so that the Old Malay population who could not adjust to their lifestyles and their high optimisms decided moved inland.

\section{The Pattern of Economic Activities of Gayo Tribe}

Gayo tribe is an expert in making a living. The following describes some forms of economic business activities of the Gayo tribe:

\section{a. Berume}

Berume is the oldest business of the Gayo people ${ }^{8}$, especially the people around the lake, which was once famous for rice barns in the Gayo Highlands. Field activities began from post lues striped (paddy fields abandoned in the middle) with the activation process as follows:

Mumelah (hoe the land)

The process of planting paddy begins by manually capturing land both individually and collaboratively ${ }^{9}$. There are also mumelah activities that involve plowing (munengel) ${ }^{10}$ with the help of a horse, where the plow is made of wood. Also attached to the iron is a plow knife on the end of the wood in pebengkolanbajak (baluhen).

Munyuk Seme (sowing rice seedlings)

This activity is carried out after Kejurun Belang (customary adat expert in the village) observes natural phenomena as a sign that it was permissible for the community to start sowing rice seedlings on neatly fenced land for up to one month.

\section{Munyeras, Mumatal}

Munyeras is cleaning the grass while softening the soil, which is similar to plowing unless the ceras were made of fingered wood pulled by a horse's tail. Mumatal is patching the embankment or plot boundary of rice fields by digging the already soft soil and attaching it to the front of the paddy field, then polishing it so that it is smooth and beautiful.

\section{Mujergut and Munomang}

This involves the people going into the fields, and all levels of the society are in the fields for mujergut (uprooting rice seeds) and cultivating 
(munomang). During the munomang activity, all family experts, handatolan, come together to perform this activity until they finish planting rice.

Mulamut (weed the grass)

After more than a month, when the planted rice looks green, the next activity would be mulamut, the weeding of the grasses that have grown around the rice. During this period, while waiting for the rice to bear fruit, the farmers would also plant long beans, corn and sweet potatoes in the boundary of the rice field plot.

Muniyo (repel birds)

After several months and when the rice has grown bigger, the rice starts to bear fruit which begins with the slurry in which the rice stems start to grow like a pregnant woman, and then the rice fruit comes out through the stem. Sometimes later, as the fruit and rice grains begin to fill, sparrows (tumpit) will start to visit the rice farms in groups to eat the crops, and this will make the farmers also begin to visit their farms often so as to repel the birds.

Berbengkon, Belide, Berdun dan Bertali

As the period of rice harvest approaches, several works will be carried out. The first one is known as Berbengkon (bones making roofs like thatched roofs). Old bamboo will be split into small sizes, such as the size of the big toe ${ }^{11}$. Belide is bamboo used as a tool to hold rice stems so that they do not fall to the ground.

Munuling and Mujaik (slicing and glancing at rice)

After the rice turns yellow and before the harvest, there would be seladang (building the hut for rice) and benyang is established (as a tool for separating pulp and rice), with wind power (munangin) or (harvest) is carried out. Here, all the people will go into the rice fields like a people's party simultaneously harvesting rice. Usually, rice harvesting (sabit) is carried out by women; the stalks of rice are cut off and then tied with the rice stem itself, called raden. After the rice raden is dry, then the men or young men lift the raden to Seladang, known as muminuh, using a splint ${ }^{12}$. Afterward, seladang is filled with raden-reden rice arranged in such a way and left for one or two weeks, then mujeik (shaking) rice is done. The activity of glancing at rice was increasingly lively like a people's party, which was carried out by these farmers. Then the rice that has been 
gazed and cleared is stored in the rice barn (keben) for the family food stock. Unused rice fields are then made into vegetable gardens.

\section{b. Berempus (Plantation Business)}

Other Gayo community businesses include berempus (gardening). This is done by planting perennials such as coffee, and fruit plants and cinnamon, and other horticultural plants. The following are presented by Gayo smallholders as follows:

Empuskupi (coffee garden) and Fruits Coffee Gardens The working process of coffee gardening starts from seedling, then the new six-month-old seedlings are planted into a dug hole measuring $1.5 \mathrm{x}$ 1.5 meters, and it is left for the necessary duration of time. The coffee plant is treated so that it grows big so that when the top is cut off ${ }^{13}$, the stem gets fatter and bears heavy fruits.

Empus Sayur-Mayur (horticulture)

Gayo farmers make use of their gardens for several purposes. For instance, they plant vegetables in some parts of their coffee plantations, and both crops are planted in special areas. Also, rice farmers use their rice fields to grow vegetables and fruits.

\section{c. Berkurik Itik (Livestock Business)}

The Gayo people are known to be very industrious people because, in addition to cultivating rice fields and gardening, they also rear livestock. Even though the rearing of livestock is not their main business, they still do it seriously. The livestock business includes the rearing of:

Bekoro (buffalo)

This animal is used for clearing the land needed for the cultivation of rice. Also, buffalo meats are sold to the community for consumption.

Berlemu (ox)

This is used the same way as the buffalo in the maintenance system. However, some make their cages specifically close to their homes.

Berkaming Bebiri (goats and sheep)

These serve as additional but temporary income sources for the farmers. Although the population of animal breeders is very limited, yet they are needed for aqiqah, vows and qurban. Like other animals, the goats and sheep are kept by their owners and are released at every striped season. 
Berkurik Beritik (chicken and duck)

The rearing of these birds is the most classic business in the Gayo tradition. This tradition has existed since the period of the ancestors of the Gayo people, and one proof of this is the sound of the morning rooster which has been used in the Gayo mars "Tawar Sedenge" with footage (pengenko so tok ni korekso = listen to the chicken's voice) ${ }^{14}$, and which is now a compulsory song along with the national anthem of Indonesia in official government events. The rearing of chickens and ducks is a hobby that is dear to the Gayo people as these two birds are easily seen in the vicinity of human beings.

Berkude (horse)

This animal is reared with specific efforts in the tradition of the Gayo people, but even this is not much fun when it comes to riding it, as it was released in luesbelang and we occasionally see it on this vast land.

Mungaro Akang (deer hunting)

There were a handful of residents who hunted deer in the Gayo forest before the 1980s. Although these people cannot be categorized as breeders, yet they shouted (mutauk) in the middle of the forest so that deer and other types of animals are startled and are captured. At times, deers are caught in the forest with the help of sniffer dogs trained for hunting.

\section{d. Bergule (Fisheries Sector Business)}

The traditional fishermen are generally involved in the fishing business because the Danaw Laut Tawar area has several types of wild plants that live in their lake. Also, fishing is done to meet the needs of various families. Therefore, the efforts put into this business are not in vain because it helps parents get fish for daily rice dishes. The types of fish found in this lake are Depik, eyas, relo, poignant fish, mujahir, denung/lindung, bado/cork, friend, keperas, peres, bawal, mut (catfish), kerup/sepat, jejolong, carp, indigo, and eel ${ }^{15}$. There are a lot of ways or models used by the Gayo residents to find fish even from ancient times ${ }^{16}$, but the most common methods include:

Mudoran or catching fish by mugerle (surprise)

This is usually done on holidays with friends since fishing activities are carried out from morning hours till the completion of the exercise. 
Berebetik (the fishing line)

The residents often make their fishing lines with palm fiber color, and it is usually about one hundred meters long. However, the food placed in the fishing line issesut (ground animal) orketol rok (worm) obtained from the rice fields.

Menime (drain)

They also dig ditches in paddy fields where there are some trenches (shelves) that have many fishes at a certain time.

Muneldik (bamboo and thread)

They also tie a thread to the end of a wood which is usually made of bamboo or white flower stem, and put a large worm (ketol rok) on it and wrap it around, then they put the fish food into the ditch, but it must start from the downstream of the ditch.

Munekik (fishing)

This is often carried out by the community both in rice field ditches, in dams, in the Kala river and the fresh sea.

Menangil (fishing rods and sange)

They could also tie fishing rods to several pieces of sange (a tree that is not submerged in water).

Mubengel (lake grass made into circles)

The circle continues to be rolled and herded to the edge of the beach until it shrinks so that fish can be caught.

Menamawawu (bubu)

This can be done in paddy fields both in the dry and rainy seasons. In the dry season, usually, the fish goes down to the lake so that the mouth of the pulp is upstream, whereas, in the rainy season, the fish usually go upstream to chase clean water so that the mouth of the bubu is mounted downstream.

Berjelabu

This is usually carried out during the rainy season where the fishes are tamarind.

Mudurung, munyekot and munube

These three methods are interrelated because munyekot involves trampling on the jenu tube (gummy grass), which if destroyed in the upstream of the trench, the fish will be poisoned by grass so that it goes downstream then the fish goes into the bubu already in the water. 


\section{Munyangkul and Depisik}

These represent the most interesting sides of the fishing business because, from ancient times, the tradition of embracing depik was already passed down for generations. Along the shores of Lake Tawar lie hundreds of detectors (jermal), by erecting a stilt house that juts into the sea and making the courtyard to also jut into the middle of the lake made of bamboo hemispheres. In the house, there is a kitchen where cooking is done, and this is also the place for carrying out muniru (heating).

\section{Mungekal}

This is a fish catching method that involves attaching a rope and fishing line on a pole and a bojok (an old and dried pumpkin).

Berserue, Beluni

This is almost the same as bubu, only that it has a bud shape and in the middle, there is an entrance (segapa), fish dishes have been placed in this series, such as bran or other food so that the fish will go into it.

\section{Munyerampang}

This involves spearheading the fishing process done at night by tying a peteromak light at the end of the boat with two fishermen standing at each end of the boat and one of them rowing the boat.

\section{e. Entrepreneurship}

The women in Gayo have many skills for making various Gayo foods, namely:

Lepat (timpan)

Gutel (rounded flour)

Cucuris food made from flour and then mixed with brown sugar water Berahrum

Temping and Gegaluh are two of the most pleasant typical foods, made from still rice, both of which are fried first and then ground and separated from the pulp. The marinade is coconut which is mixed with brown sugar Apam Serabi

Kekaras, Engkul, Lue and Sagon

\section{f. Tourism}

One of the competitive advantages of Gayo is tourism. Even though 
this potential has not been maximally promoted, there is now a five-star hotel, "Renggali Hotel," belonging to Gayo Executives. As for the surrounding community, tourism business can influence independent businesses, especially during the holiday seasons such as Islamic holidays and National holidays. At these times, the Danau Laut Tawar tourist area is flooded with local tourists and those outside the Regency. During this period, the residents open new businesses around this fresh sea lake tourist attraction center, and from this tourism environment, the community has created a wide variety of businesses, such as:

Vendors for food, drinks, fruits and even souvenirs such as accessories, Gayo-made accessories such as bags, shoes, caps, and filed tablecloths are sold along the shore of the lake. Travelers buy food and beverages offered by the surrounding residents in a bid to meet their nutritional needs.

Providing seating stalls in the form of huts as shelters for tourists. Landowners provide these stalls in the lake area, and prices are related to the distance between the road and the lake.

- Providing children's play facilities in several places, such as wheels and piggy banks, wedding receptions to provide comfort and entertainment for the travelers' family members.

Historical places of ancient human legends, such as the daughter of Pukes facility, are put in place by landowners. Travelers are assisted in entering into the cave to witness the contents and history of the events of the daughter of Pukes - there are miniatures in this cave. Even in the cave, there is water dripping from above said to have healing abilities, and is sold to travelers to treat eye pain.

Motorboats to cruise and spin around the lake as entertainment for the family members of travelers. Some rent used tires for bathing on the beaches of the lake.

\section{RESEARCH METHOD}

This study used a qualitative approach (Moleong, 2014: 11). Qualitative approach processes, hypotheses, declines, data analysis and data conclusions were conductedby using aspects of trends, non-numerical calculations, descriptive situational and in-depth interviews. A qualita- 
tive approach tries to explain reality using descriptive explanations in sentence form (Pujileksono, 2015 : 35).

This research applied a descriptive approach to picture a situation or event that is not accompanied by a hypothesis. According to Pujileksono (2015 : 21), descriptive research is aimed at solving actual problems faced now, and it aims at collecting data or information to be compiled, explained and analyzed. Through the descriptive research, the researchers gathered useful information and analyzed the integration of tawhid values with their trading tradition. The data analysis technique started with observing the available data and then interviewing the native Gayo people. Those activities were carried out to describe the study results to make it easy to understand and interpret data.

\section{DISCUSSION}

\section{Integration of Tawhìd Value (Religion Value) With Trade Tradition of Gayo Tribe}

\section{a. Motivating Theological Values}

The Gayo tribe community, as well as other Muslims, treat the faith as the foundation of their lives, and similarly, their lives are based on faith as described by Allah in QS. Ibrahim 24:
Meaning: "Do you not see how God has made a good parable of a sentence like a good tree; its roots are firm and its branches (towering) into the sky. The treegives its fruit at every season with the permission of the Lord. God made the parables for humans so that they always remember."

The sentence that is referred to in the above verse is the sentence of tawhīd, and this saying is a call unto virtue in order to prevent evil and encourage good deeds. This sentence of tawhìd is found in the sentence laailaa ha illallaah. Since the time of Prophet Ibrahim AS, such sentences have been used as the basis of the life of Muslims. In fact, a Muslim must be like a staple of wood mentioned by Allah above with a character having aqeedah (sentence of Thayyibah) that is strong, good and is of 
true worship, with muamalah (harmonious relationship between humans), and having a noble character, because all of life's activities must be built on the basis of this monotheism, including economic activity. Economics is generally defined as the study of human behavior in its relations with scarce productive resources to produce goods and services and distribute them for consumption ${ }^{17}$.

For the Gayo community, the economy is the establishment of a business or work for living purposes, which is called livelihood. Gayo tribe's livelihoods include hunting, fishing, in rivers and in lakes, farming different crops, rearing livestock, trading and working as employees ${ }^{18}$. As a person who obeys the teachings of Islam, the Gayo tribe is a member of the faith, so all life's needs must be based on the value of faith. In the Al-Quran, it is stated that there is a significant relationship between believing in Allah and getting rizq, which is contained in Al-Ankabut 16-17:

Meaning: "Verily what you worship besides Allah is an idol, and you make a lie [1146]. Surely what you worship besides Allah is not able to give you sustenance; Then ask for sustenance from Allah, and worship Him and give thanks to Him. Only to you, will we return."

Especially regarding property, Gayo people still refer to Al-Quran as in the words of Allah in QS Al-Baqarah 22:

Meaning: "He is the one who made the earth as a stretch for you and the sky a roof, and He sent down water (rain) from the sky, then He produced with it all fruits as a provision for you; therefore do not make allies to God [30], even though you know."

The Gayo people conduct their economic activities based on orders and stay away from Allah's prohibitions by seeking legal and good rizq (QS16: 114). They try to stay in a halal way and avoid illegal business so that the assets obtained are truly clean. In order to obtain a halal and clean property, it must be sought by working hard and maximizing 
efforts. Working the Islamic way can only be done in an atmosphere of honesty and sincerity because there is no drive stronger than faith ${ }^{19}$. In addition, life in Gayo is patterned according to the principle of balance in the interests of this world and for the hereafter, meaning that they try to strike a balance between the interests of the people of this world in their attempts to earn a living while emphasizing the fact that worship must also be carried out together with it in order to attain Allah's pleasure and stay away from the pollution that they could encounter in the environment (QS 28:77). Gayo people are strong in their faith, and their motivation to work comes from their souls, and people like that get true blessings. And this conforms to the statement of Yusuf Al-Qardawi that "the believer works because of the will of his heart, because of the call and command from within him, not because a whip drives him from behind." They work with inner encouragement that trusts in God and His Message because they remember their duties and obligations from God to prosper the earth and master nature ${ }^{20}$.

\section{b. Motivation of Cultural Values}

Many of Gayo's tribal ancestors' advice was found in the Gayo proverbs, including the physical noise (so that it really worked), not aiming (effectively working), not tingling (strong working). There are even lyrics in the Gayo march called "Tawar Sedenge," which are compulsory songs done during official government events and community organizations and which are even entrenched in the education of the Gayo people. It was even said that in the lyrics of the Indonesia Raya song, that there was one verse that reads: "uwetmi ko so the people of Gayo beluhmi ko muniri so Lautijo, entidatenko burnt kelieten mongot pudederu, oyalerahmatni Tuhen, thank you, pengenko so nikorekso" (wake up O Gayo people go take a bath in the green sea (Danau Laut Tawar), do not let Mount Kelieten cry, that's the blessing from God to all of you, listen to the sound of the rooster cock). The song's lyrics are as simple as the mandate of the ancestor of Gayang's ancestors to the next generation of Gayo, to work diligently and try to get the chance to get rizq and not to just allow it to disappear. And in this life, we must gain the grace that Allah has given, if necessary, to master it like Mount Burni Kelieten (the biggest mountain in Takengon). 
There are five scales of systematic work ethic in the Gayo culture, namely: First: physical - is really working to the maximum extent, this is illustrated in a traditional word kiding kin ulu, ulu kin kiding (feet become head and head becomes feet). It means that all members of the body are involved in working with the system of thinking, planning and working. Second, bidik, working quickly to use time effectively (on time) and efficiently (appropriately), time is used properly so that useful results are produced. Third, cleverness - to use the work strategy, of course, using reason so that the work is not done in vain, so steps are taken to work not too heavy but to get good results. Fourth, mersik is a scale of work that is made great by not just working but also ensuring that the benefits that will be achieved are great for the interests of life. Fifth, mutasik is the result of the work, and this ensures that the produce from the production accumulates. If the results obtained are many, life will prosper and can be shared with others.

In addition, there are eight values of life-based on the Gayo culture, these values are:

First: Genap mufakat (deliberation), even consensus means an agreement is reached in deliberation, which is taken by deliberation in all matters. Second, the mandate is to be trusted with or handed over a position, a job and even a mandate of words and barag. Third, orderliness is a culture that is highly upheld because orderliness is akhlak al-karimah that is taught in Islam. Fourth, alang tulung beret berbantuis means to help one another, especially when there is a disaster. When it actually happens, Gayo people are quick to provide assistance to others. Fifth, compassion is a mental attitude to love the family, handaitolan, fellow Muslims even love the other creatures of Allah SWT. Sixth, setie is loyalty to parents, father, mother, family and even colleagues. Seventh, bersikekemelen is to be positively competitive, and this came up from facing and tackling the shame that has grown from infancy. Eighth, mutentu is Gayo's mental attitude that is very noble and aesthetic. It is called noble because it requires them to work regularly, to be clean, neat and beautiful. So that mutentu tends more to the regularity of appearance when working. 
In the Gayo culture, mothers always sing poetry and prayers as songs; they sing prayers to their babies and older children, especially before going to bed. One of the verses has been stated above, namely: "lailahaillah ankkuni mutuah umure gelah lanyut rezekie gelah mudah, atewe gelah mukmin tangane gelah murah". Thus, the foundation upon which their children's knowledge of Allah (thayyibah sentence) is built is found in this verse. Also, these children are taught how to pray so that they can become true believers, so that they can have a long and easy life, and so that their hands can be generous as they become givers. Every child in Gayo grows up to marry in order to establish faith so that his worship is good in relation to others' (muamalah) and so that he is able to produce akhlakul karimah as the fruit of his faith (QS. 66: 24-25).

Also, since they need the necessities of life starting from the basic ones (ad-dharuriyah) like food and drink, they actively engage themselves in various businesses such as farming rice fields, gardening, rearing livestock, fishing, and so forth. The Gayo people are used to having rice lavas (keben) in each household because they are afraid of starvation so as to be able to have seedlings to plant rice as much as possible, and the results are stored for a long time. Likewise, abundant fish in Danau Laut Tawar are easy to catch and dry in preparation, vegetables and fruits are cultivated in their gardens and they also rear livestock. So the life of the Gayo people is very prosperous. They see to the needs of their various households (al-hajiah) such as buying of supplementary foods, bicycles, radio and TV sets which almost every household can afford, through their well planned out financial-economic system. Also, their tertiary needs (tahsinat) in the form of beauty equipment, handphones, home accessories, hygiene cupboards, flowers and others items are also planned for.

In fact, the Gayo Plateau can be said to possess "a thousand grace" because it comprises fertile land that can grow vegetables, fruits and hultikultura parks. It also has beautiful Laut Tawar Lake and a variety of flora and fauna. It is as if God wants the inhabitants of Gayo Land to live in prosperity. Any crop planted in Gayo Land grows well, and any business tried in Gayo Land gets abundant rizq. But these potentials need to be explored. This makes the Gayo people be close (taqarrub) to the one who gives them sustenance, that is, Allah SWT. With the abundance of 
natural resources, it is paramount for the people of Gayo to be obedient to Allah through taqwa, meaning that the more Allah increases mercy, the more intense the quality of their service will be to God Almighty. Among the Gayo people, there is a connection between deviations from aqeedah and Islamic teachings to make rizq disappear (QS. 29: 18). Therefore, there is a relationship between the more abundant mercy shown to the people of Gayo and more obedience from them to Allah. On the other hand, the diminishing pleasure of Allah is increasingly tenuous when it concerns the relationship of Gayo people with Allah. Therefore, the Gayo Plateau has a thousand blessings that must draw its people closer to Allah, so that the rahmat continues and becomes a provision for everyday life - a thousand grace must be balanced with a thousand gratitude as in the words of Allah, "if you are grateful I will add to my favour, but if you are not grateful, my punishment will be very painful" (QS. 14: 7).

\section{CONCLUSION}

For the Gayo people to get blessing sustenance, they must have good intentions to be obedient to Allah, who gives them their blessings. They must start each business with the basic sentence and put in their maximum efforts, and be grateful to Allah for business success. The results of their work must be used to serve God and to provide income for their various families. The rest can be released as zakat, infaq and sadaqah for the mustahiq.

By capitalizing on faith and piety, these people work honestly, trustworthily, and carry out the traditions of the Gayo tribe consistently in every effort they make. In doing so, the Gayo people strictly practice Islam in their daily lives to get a blessed, prosperous and dignified life from Allah to achieve happiness in this world and in the hereafter.

Having a sense of being close to God makes the Gayo people not afraid of feeling economically deficient. The life of the Gayo community is in line and is balanced between this world and the hereafter, in the sense that all the achievements made by people in the community are regarded solely as a God's gift that will surely return unto Him.

In conclusion, it is worth mentioning that the researchers who were 
directly involved in this research also felt a very significant impact when experiencing their practice of monotheism. It gives the opportunity for each and every one of us to reflect on it in our lives so that we can become people who are truly grateful and who are always thankful to God for giving a decent life to each of His people.

\section{ENDNOTES}

In Aceh Province there are also twelve tribal sub-groups in Aceh, namely, Acehnese, Gayo, Aneuk Jamee, Singkil, Alas, Tamiang, Kluet, Devayan, Sigulai, Batak Pak-Pak, Haloban, Lekon. These tribes differ in language and culture but are united in an Aceh region. It is said that the Acehnese were still related to the Mon Khmer tribe (Campa region). Acehnese language is part of the Malay language of Austronesian Polynesia. See on Visit Banda Aceh-Aceh Indonesia.

2 Drs. M. J. Melalatoa (1982), Kebudayaan Gayo, (Jakarta: PN. BalaiPustaka), p.34.

3 There is a term from the word Aceh, the Arabs call it Asji, the French writers refer to Aceh as Acehm, Acin, Acheh, while the British call it Atcheen, Acheen, Achin. The Dutch called it Achem, Achim, Atchim, Atchem, Atjin, Atsjeh and Atjeh. One of the origins of the Acehnese designation is an ancient story of an Indian Guzarat ship that sailed to Aceh and arrived at the Tjidaih River (read: ceudah). The crew then climbed ashore to Pande Village.

$4 \quad$ Gayo language utterances have the same words used in Malaysia such as, uluh (bamboo) reeds in Malay, tingkep (window), screeching (running fast) etc. In Mandailing also found syllables such as ipon (teeth), ulu (head), manganese (eating), maridi similar to muniri means bathing, etc. So that the Gayo Tribe is close to the North Sumametra tribe as an Old Malay tribe.

5 In the traditional words, Edet urum Syeriet is the song of the urine sifet.

$6 \quad$ Researcher and writer team (1970), Monografi Kabupaten Aceh Tingkat II Aceh Tengah, (Banda Aceh: Economy Faculty UNSIYAH), p.10.

7 H. Mahmud Ibrahim (1980), Peranan Islam Melalui Adat Gayo Dalam Pembangunan Masyarakat Gayo, Makalah Seminar Ilmu Pengetahuan Dan Kebudayaan, Januari 20-25, 1986 (Takengon: Majelis Ulama Indonesia with MUI Aceh Tengah), p.2.

8 Before livelihoods in the fields developed well, rice fields were dominant for the Gayo people. Meanwhile, according to Walad, viewed from basic livelihoods up to 1972 in the four largest villages were coffee, tobacco and secondary crops (35\%), then followed by rice fields (25.5\%), the rest were teachers, administrative staff, trade and others. See in M. J. Melalatoa, Gayo Culture, (Jakarta: Balai Pustaka, 1982), p. 132.

9 In the tradition in Gayo, there are various forms of mutual cooperation (tulang tulung) such as berlat, host, mango lo, munempuh and so on, M. J. Melalatoa, Kebudayaan Gayo, p. 132.

10 Nengel is a land plowing tool drawn by a horse. This tool consists of a baluhen which is a bent wooden trunk, at the end of this baluhen there is a nengel eye (knife) that will dismantle the ground, from this baluhen is attached to another wood as the 
handle for the control device, then there is a $5 \times 6 \mathrm{~cm}$ wood perpendicular to the baluhen angle straight forward as a horse-drawn hook, there is a curved igu of wood placed on the horse's neck with its saddle, and there is an eighth rope where it is inserted in the form of flour, and there are two bridle straps from munung horse because of the control device.

11 The rope from the stem of the train can also be made as a "jangkat" in the Gayo tradition, there is a tool to lift things, especially fire wood, rice greetings, and other special items for mothers called go-to. Whereas for men it is called bertujung if caught on the head like rice, etc., but there is also "berarang" if what is brought is wood or bamboo, where the wood is placed on the shoulder and the tag handles objects that are carried.

12 Splint is made from burlap which is cut in two right sides and is clipped with wood and tied with a rope, in the middle of which there is branching wood (kekawit) into this tool, placed raden (clump of rice) and then transported (ijujung) to seladang.

13 Lucky coffee is when this coffee tree is about one meter high, cut so that the trunk and branches become fat and will bear heavy fruit, if coffee is not made fortune then the coffee is higher and taller and less fruitful and even difficult to pick it.

14 Mars Gayo which is called "Tawar Sudenge", one of the verses reads ... "the party is asking for nikorekso, (listen to the sound of chickens crowing)" so wake up early for prayer and work to find God's gifts.

15 A.R. Hakim Aman Pinan, Daur Hidup, hal. 38.

16 Tools for catching fish in Gayo are Kik Sawa, Jo, Mangka, Ngelok, Nekik Brawang, Nancak, Begerep, Beketor/Bermemin, Murodok, Mulongkop, Salir, Nin, Dawe, Nelping, Rawit, Kik Sawe, Munyamar, Nekik Bado, Dekik, Nantus, Didisen, Berserue, Nenekil, Kekal, Murebetik, Munangil, Modoran, Menyangkul, Muneldik, Wawu ni Li, Nujele/Munyempak, Munyerampang, Munyekot, Mubengel, Mnyengkek, Meneni, Munyerkap, Munyisik, Batur, Gedegom, Crkap

17 Monzer Kahf, Ekonomi Islam (Yogyakarta: Pustaka Pelajar, 1995), p.2.

18 Drs. M. J. Melalatoa, Kebudayaan Gayo (Jakarta:Balai Pustaka,1982), p.130.

19 Drs. M. J. Melalatoa, Kebudayaan Gayo (Jakarta:Balai Pustaka,1982), p.130.

$20 \quad$ Yusuf Al-Qardawy, Iman, p.266.

\section{REFERENCES}

Ahmad Tafsir. "Ilmu Pendidikan Dalam Perspektif Islam". (Bandung: Remaja Rosdakarya). 2005.

AR. Hakim Aman Pinan. "Daur Hidup Gayo". (Takengon: ICMI Orsat Aceh Tengah). 1998.

AR. Hakim Aman Pinan. "Kekeberen Cerita Rakyat Gayo". (Takengon: Cipta Pustaka dan Yayasan Sengeda Seni Gayo). 2004.

AR. Hakim Aman Pinan. "Pesona Tanoh Gayo". (Takengon: Pemda A.Tengah). 2005.

Ayodhyoa dan Moch Mahfud. "Suatu Penelitan Tentang Perikanan Darat Di Danau Laut Tawar". (Bogor: LPD). 1969.

Egon G. Guba dan Yvonna S. Linconln. Effective Evaluation. (San Fransisco: Jossey Bass Publishers). 1981.

Burhan Bungin. Metodologi Penelitian Kuantitatif. (Jakarta: Raja Grafindo Press). 2001. Fakhruddin Muhammad Ar-Razi (tt). Tafsir Fakh ar-Razi (Beirut: Dar al-Fikri). 
Hatta Hasan Aman Asnah. Gayo Masyarakat Dan Kebudayaan. 1996.

HAR Latif. Pelangi Kehidupan Gayo Dan Alas. (Bandung: Kurnia Bupa). 1995.

Haryoto Kusno Putranto. "Dampak Ekologis Industri Pabrik Semen Di Kawasan Ekosistem Leuser”. (Makalah, Seminar Lingkungan Hidup). 1977.

Harjani Hefni. The 7 Islamic Daily Habits. (Jakarta: Pustaka IKADI). 2009.

Lexy J. Moleong. Metode Kualitatif. (Bandung: Remaja Rosdakarya). 2007.

Kamaluddin dkk (ed). Dari Tanah Gayo Ke Kota Medan Perjalanan Prof. Dr. Sukiman, M.Si Mengapai Cita. (Medan: Perdana Publishing). 2016.

KP. Ahmad Azhar Basyir. Refleksi Atas Persoalan Keislaman. (Bandung: Mizan). 1993.

Mahmud Ibrahim. Mujahid Dataran Tinggi Gayo. (Takengon: Yayasan Maqaman Mahmuda). 2001.

Mahmud Ibrahim. Peranan Islam Melalui Adat Gayo Dalam Pembangunan. (Takengon: MUI Aceh Tengah). 1980.

Mahmud Ibrahim Dan AR. Hakim Aman Pinan. Syariat dan Adat Istiadat. (Takengon: Yayasan Maqaman Mahmuda). 2002.

M. Mansyur Amin (ed). Teologi Pembangunan Pandangan Baru Pemikiran Islam. (Jakarta: LKPSM-NU). 1989.

Maurice Bucaile. Bibel, Quran dan Sains Modern. (Jakarta: Bulan Bintang). 1979.

Moleong, J., Lexy. Metode Penelitian Kualitatif Edisi Revisi. PT. Remaja Rosdakarya, Bandung. 2014.

Muhammad Said. Aceh Sepanjang Abad. (Medan: Harian Waspada). 1990.

Muhammad Rusli Malik. Puasa Menyelami Arti Kcerdasan Intelektual, Kecerdasan Spritual dan Kecerdasan Emosional di Bulan Ramadhan. (Jakarta: Pustaka Zahra). 2003.

M. Quraish Shihab. Membumikan Al-Qur'an. (Bandung: Mizan). 1992.

M. Quraish Shihab. Wawasan Al-Qur'an. (Bandung: Mizan). 1996.

Mukhlis Paeni. Riak di Laut Tawar. (Yogyakarta: UGM Press). 2003.

M. J. Melalatoa. Kebudayaan Gayo. (Jakarta: Balai Pustaka). 1982.

M. Umar Capra. Islam dan Tantangan Ekonomi. (Jakarta: Gema Insani Press). 2000.

M. Suparmoko. Ekonomi Sumber Daya Alam dan Lingkungan Hidup. (Yogyakarta: BPFT). 1977.

MoP. Nasir. Metode Penelitian. (Jakarta: Ghalia Indonesia). 1988.

Monzer Kahf. Ekonomi Islam. (Yagyakarta: Pustaka Pelajar). 1995.

Mustamir. Rahasia Energi Ibadah Untuk Penyembuhan. (Yogyakarta: Lingkaran). 2007.

Pujileksono, Sugeng. Metode Penelitian Komunikasi Kualitatif. Malang: Kelompok Intrans Publishing. 2015.

Rehngena Purba. "Kajian Historis (Antropologi) Masyarakat Gayo, Alas dan Singkil". (Medan). 2001.

Shaleh Al-Khalidy. Maa Qashashis Shabiqina fi al-Qur'an, Alih Bahsa Budi Utomo. (Jakarta: Gema Insani Press). 2000.

Sidi Gazalba. Masjid Sebagai Pusat Ibadat dan Kebudayaan Islam. (Jakarta: Antara). 1962.

Syukri. Sarakopat: Sistem Pemerintahan Tanah Gayo dan Relevansinya Terhadap Pelaksanaan Otonomi Daerah. (Takengon: Hijir Pustaka Utama). 2006.

Sukanto Reksohadiprodjo. Ekonomi Sumber Daya Alam Eु Energi. (Yogyakarta BPFT). 1994.

Sayyid Hossen Nasr. Islam dan Krisis Lingkungan. (Jurnal: Islamika). 1994. 
Taufik Abdullah. Agama dan Peubahan Sosial. (Jakarta: Rajawali). 2002.

Taufik Abdullah (tt). Agama dan Etos Kerja dan Pembangunan Ekonomi. (Jakarta: LP3ES). 1986.

Jalaluddin Rahmat. Metode Penelitian Komuniksi Dilengkapi Contoh Analisis Statistik. (Bandung: Reamaja Rosdakarya). 1995.

Yusuf Al-Qardhawy (tt). Iman dan Kehidupan. (Jakarta: LP3ES). 1983.

W. Lawrence Neuman. Social Research Methods Qualitative And Quantitative Approaches. (Boston and London: Allyn \& Bacon). 1977. 